\title{
PENGGUNAAN MASSAGING SKILLS VIDEO UNTUK IBU EFEKTIF MENSTIMULASI PERKEMBANGAN MOTORIK BAYI
}

\section{[THE USE OF THE MASSAGING SKILLS VIDEO FOR MOTHERS EFFECKTIVELY STIMULATES DEVELOPMENT OF THE BABY'S MOTORIC]}

\author{
Elisabeth MF Lalita, Amelia Donsu \\ Poltekkes Kemenkes Manado Jurusan Kebidanan \\ e-mail : lisalalita08@gmail.com \\ DOI : 10.47718/jpd.v8i02.1238
}

\section{ABSTRAK}

Latar Belakang: Sekitar 5 sampai 10\% anak diperkirakan mengalami keterlambatan perkembangan. Salah satu perkembangan anak yang penting untuk dipantau adalah perkembangan motorik karena banyak kinerja kognitif yang berakar pada keberhasilan perkembangan motorik. Pijat dapat membantu perkembangan keterampilan motorik bayi. Tujuan: untuk mengetahui efektifitas pijat bayi dan promosi kesehatan media video terhadap perkembangan motorik bayi berdasarkan skrining KPSP. Metode Penelitian: Desain penelitian ini pre experimental desaign dengan rancangan one group pretest posttes. Sampel dalam penelitian yaitu seluruh ibu yang mempunyai bayi yang tinggal di Winangun, jumlah sampel 14 responden ibu dan 14 responden bayi. Instrumen dalam penelitian ini menggunakan Video, KPSP, dan Checklist. Teknik analisa data menggunakan uji Paired Simple T-Test. Hasil penelitian yaitu pijat bayi efektif meningkatkan perkembangan motorik bayi dengan nilai $p$ value 0,001 dan promosi kesehatan dengan video terbukti efektif meningkatkan kemampuan ibu melakukan pijat bayi dengan nilai $p$ value 0,001 . Kesimpulan: pijat bayi merupakan teknik yang sederhana dan efektif mendukung perkembangan bayi. secara keseluruhan. Peran ibu sangat penting dalam proses tumbuh kembang bayi sehingga perlu mengeksplorasi pengalaman belajar ibu melakukan pijat bayi serta membangun hubungan emosional dan fisik dengan bayi.

Kata Kunci : Pijat bayi, Perkembangan motorik, Skrining 


\section{ABSTRACT}

Introduction: About 5 to $10 \%$ of children are estimated to have developmental delays. One of the important children's developments to monitor is motor development because a lot of cognitive performance is rooted in the success of motor development. Massage can also help the development of baby motor skills. The research objective was to determine the effectiveness of infant massage and health promotion video method on infant motor development based on KPSP screening. Method: This type of research is a pre-experimental design with a one group pretest posttest design. The sample in this research is all mothers who have babies who live in Winangun I, the total sample is 14 respondents. The instruments in this study used video, KPSP, and checklists. The data analysis technique used the Paired Simple T-Test. Results: The results of the study were infant massage was effective in increasing motoric development of infants with a $p$ value of 0.001 and health promotion video method was proven to be effective in increasing the ability of mothers to massage babies with a $p$ value of 0.001 . Conclusion: Baby massage is a simple and effective technique supporting the development of the baby. The role of the mother is very important in the process of growing the baby so it is necessary to explore the learning experience of the mother doing the baby massage as well as building emotional and physical relationship with the baby.

\section{Keywords: Massage baby, Motor Development, Scrinning}

\section{Perkembangan bayi didefinisikan sebagai aspek-aspek dari} pertumbuhan yang melibatkan fisik, mental, perubahan emosional dan sosial. Ini adalah peningkatan keterampilan secara progresif dan kapasitas fungsional dan sebenarnya perubahan kualitatif pada anakanak kinerja (Rezaeian, 2013). Perkembangan anak adalah faktor penentu penting kesehatan seumur hidupnya dan tahun-tahun awal kehidupan dianggap sebagai peluang mendasar untuk pertumbuhan, pengembangan dan kerentanan (Anderson, et al. 2003). Tahap perkembangan adalah tahap-tahap yang harus dilalui bayi dalam 
proses perkembangan motorik sesuai dengan umur dan harus melalui prinsip perkembangan motorik yang benar, sedangkan perkembangan motorik yang dimaksud adalah proses tumbuh kembang kemampuan gerak seorang anak yang dikoordinasi oleh saraf, pusat saraf dan otot. Secara umum perkembangan motorik dibagi menjadi dua yaitu motor kasar dan motor halus. Oleh karena itu, bayi sangat peka terhadap lingkungan dan membutuhkan asupan gizi serta stimulasi yang baik untuk pertumbuhan dan perkembanganya. Pertumbuhan dan perkembangan masa bayi terbagi empat bagian, usia 0-3 bulan, 4-6 bulan, 7-9 bulan dan 10-12 bulan (Kementrian Kesehatan, 2009).

Sekitar 5 sampai $10 \%$ anak diperkirakan mengalami keterlambatan perkembangan. Data angka kejadian keterlambatan perkembangan umum belum diketahui dengan pasti, namun diperkirakan sekitar 1-3\% anak di bawah usia 5 tahun mengalami keterlambatan perkembangan umum (Watson, 2005). Fenomena yang terjadi di masyarakat bahwa masih banyak anak-anak mengalami keterlambatan pada pertumbuhan dan perkembangan pada anak mereka. Hal ini terjadi disebabkan orang tua kurang memahami akan pentingnya proses serta tahapan pertumbuhan dan perkembangan pada anak mereka, sehingga mereka kurang memberikan stimulasi sejak dini pada anak mereka, padahal mereka mempunyai kemampuan untuk melakukan stimulasi dini pada anak mereka sendiri (Hurlock, 2002). Balita di Indonesia pada tahun 2008 berjumlah 23,7 juta jiwa atau sekitar $10,4 \%$ dari total penduduk 
Indonesia. Namun hingga saat ini, angka gangguan perkembangan anak di Indonesia masih cukup tinggi. Profil kesehatan Indonesia tahun 2011 menunjukkan bahwa 13-18\% anak balita mengalami keterlambatan perkembangan.

Optimalisasi perkembangan diperlukan adanya interaksi antara anak dan orangtua, terutama peranan ibu sangat bermanfaat bagi proses perkembangan anak secara keseluruhan karena orangtua dapat segera mengenali kelainan proses perkembangan anaknya sedini mungkin dan memberikan stimulus tumbuh kembang anak yang menyeluruh dalam aspek fisik, mental, dan sosial. Salah satu faktor resiko yang penting dan berhubungan dengan interaksi ibu dan anak adalah pemberian stimulasi (Suryawan, 2012).

Stimulasi yang tepat terhadap indera sentuhan bayi secara positif memengaruhi perkembangan psikososial dan mendorong keterikatan antara ibu dan bayinya. Pijat bayi dapat membantu menambah berat badan dan pertumbuhan keseluruhan, serta lamanya waktu bayi tidur dan seberapa nyenyaknya mereka tidur. Ini dapat digunakan untuk menenangkan bayi yang kolik dengan mengurangi stres, memperdalam ikatan dengan orang tua dengan melepaskan hormon oksitosin (hormon yang terasa enak) dan mengurangi kadar kortisol (hormon stres) pada bayi dan pengasuh. Pijat juga dapat membantu perkembangan keterampilan motorik bayi (7). Demikian studi The Effects Of Baby Massage On Attachment Between Mother And Their Infants, dimana semua ibu dinilai pada hari pertama dan terakhir dari periode studi 38 hari. Pada kelompok 
eksperimen, bayi menerima sesi terapi pijat 15 menit setiap hari selama 38 hari. Hasil penelitian Ada perbedaan yang signifikan antara kelompok ( $p<0,05$ ). Maka dapat disimpulkan bahwa pijat bayi efektif dalam meningkatkan keterikatan ibu dengan bayi (Ays, et al. 2012)

Berdasarkan penelitian The Effect Of Baby Massage On MentalMotor Development Of Healthy Full Term Baby untuk menentukan efek dari pijat bayi pada perkembangan mental motorik bayi sehat jangka panjang, dimana para ibu dididik melakukan pijat bayi setelah kelahiran, diminta untuk menerapkan pijat 15 menit sekali sehari selama enam bulan, dan hasil menunjukkan perkembangan motorik dapat ditingkatkan dengan pijat bayi pada bayi cukup bulan yang sehat (Inal, et al. 2012)

Demikian juga penelitian lain menyelidiki efek pijatan pada anak-anak dengan keterlambatan perkembangan. Tiga puluh enam anak-anak usia 1-3 tahun, Kedua kelompok terus menerima intervensi rehabilitasi rutin, sedangkan kelompok pijat tambahan menerima 20 menit pijat dua kali seminggu selama 12 minggu. Hasil ini menunjukkan bahwa pijat secara efektif dapat meningkatkan pemrosesan motorik dan sensorik pada anak-anak (Wei-Peng Lu, et al. 2018)

Pentingnya memberikan pemahaman dalam tentang proses tahapan pertumbuhan dan perkembangan pada anak serta meningkatkan kemampuan orang tua maka dapat diberikan promosi kesehatan. Promosi kesehatan mempunyai peranan yang sangat 
penting dalam proses pemberdayaan masyarakat yaitu memperoleh pembelajaran dari, oleh dan bersama masyarakat sesuai dengan lingkungan sosial budaya setempat, agar masyarakat dapat menolong dirinya sendiri dibidang kesehatan (Fitriani, 2011). Penelitian Arum, dkk (2018) melaporkan pengaruh pemberian informasi terhadap pengetahuan ibu dengan bayi tentang pijat bayi sehingga responden dapat mengaplikasikan ilmu yang diperoleh dalam kehidupan seharihari.

\section{METODE PENELITIAN}

Metode yang digunakan yaitu pre experimental desaign dengan rancangan one group pretest posttest. Teknik analisa data menggunakan uji Paired Simple T-Test. Pengambilan sampel diambil secara Purposive Sampling dengan kriteria inklusi bayi tidak panas atau suhu tubuh normal, ibu tidak buta dan tidak tuli serta bersedia menjadi responden. Jumlah ibu dan bayi yang di ambil sama, masingmasing sebanyak 14 responden. Instrumen dalam penelitian ini menggunakan Video, Kuesioner skrining KPSP, Checklist penilaian keterampilan ibu.

Cara pengumpulan data dilakukan secara home visit dengan melakukan pengukuran suhu tubuh bayi dan ibu dan skrining Covid 19 dengan kuesioner. Selanjutnya pengambilan data secara umum dan Peneliti mengajarkan ibu untuk melakukan pijat dengan menggunakan video yang diberikan oleh peneliti. Pijat dilakukan 15 menit setiap minggu 2 kali dan selama 3 minggu. Pada hari terakhir keterampilan ibu dibuatkan video juga sebagai penilaian dan 
HASIL DAN

PEMBAHASAN

\section{dokumentasi.}

Penilaian perkembangan motorik bayi dilakukan dua kali sebelum dan sesudah dipijat dengan skoring 0 -10 berdasarkan Skrining KPSP sesuai umur bayi 0-3 bulan, 4-6 bulan, 7-9 bulan dan 10-12 bulan. Sementara penilaian pada kemampuan ibu untuk melakukan pijat bayi dilakukan dua kali sebelum dan sesudah dengan menggunakan video dengan skoring 0-16 berdasarkan checklist penilaian keterampilan ibu.

Karakteristik individu pada tabel 1 yaitu usia ibu rata-rata dalam penelitian kelompok umur 20-35 tahun yaitu 11 responden (78,6\%), sementara untuk usia bayi sebagian besar 4-6 bulan yaitu 7 orang (50\%). Tingkat pendidikan reponden yaitu sekolah menengah atas sebesar 92,86\%, dan pekerjaan ibu bekerja sebagai pengatur rumah tanggah berjumlah $85,7 \%$.

Tabel 1. Karakteristik Responden

\begin{tabular}{llcc}
\hline \multicolumn{2}{c}{ Karakteristik } & $\mathrm{N}$ & $\%$ \\
\hline Umur ibu & $<20$ & 3 & 21,4 \\
& $20-35$ & 11 & 78,6 \\
& $>35$ & - & - \\
\hline Usia Bayi & $0-3$ & 3 & 21,42 \\
& $4-6$ & 7 & 50 \\
& $7-9$ & 2 & 14,28 \\
& $10-12$ & 2 & 14,28 \\
\hline Pendidikan & SMP & - & - \\
& SMA & 13 & 92,8 \\
& Sarjana & 1 & 23,5 \\
\hline Pekerjaan & IRT & 12 & 85,7 \\
& PNS & - & - \\
& Swasta & 2 & 14,3 \\
\hline
\end{tabular}


Tabel 2. Perkembangan Motorik Bayi Sebelum dan Sesudah Pijat

\begin{tabular}{ccccc}
\hline Variabel & Mean & Mean Difference & $\mathrm{N}$ & p value \\
\hline Pre-Test & 8,07 & -0.929 & \multirow{2}{*}{14} & 0,001 \\
Post-test & 9,00 & & & \\
\hline
\end{tabular}

Berdasarkan tabel 2 Perkembangan motorik bayi secara signifikan terjadi perubahan pada bayi sebelum dan sesudah dilakukan therapi nilai mean 8,07 meningkat menjadi 9,00. Penilaian perkembangan motoric bayi dilakukan sebelum pijat bayi, penilaian perkembangan motoric bayi berdasarkan KPSP menurut skema umur bayi. Pijat dimulai di kaki, paha, perut, tangan dan area wajah. Setiap area dipijat perlahan dan lembut. Saat memijat, ibu menjaga kontak mata dan "berkomunikasi" dengan bayinya.

Tabel 3. Keterampilan Ibu Melakukan Pijat Sebelum Dan Sesudah Menggunakan Video

\begin{tabular}{ccccc}
\hline Variabel & Mean & Mean Difference & N & p value \\
\hline Pre-Test & 2,93 & $-8,000$ & 14 & 0,001 \\
Post-test & 10,93 & & & \\
\hline
\end{tabular}

Berdasarkan tabel 3 menunjukkan Rata-rata responden tidak tahu teknik memijat bayi, namun setelah diajarkan secara langsung oleh peneliti dan memberikan promosi kesehatan dengan video pemijatan bayi pada responden, hasil akhir memiliki peningkatan keterampilan responden secara bermakna. Penilaian keterampilan responden dengan checklist, penilaian dilakukan 2 kali sebelum dan sesudah dengan menggunakan video. 


\section{PEMBAHASAN}

Hasil evaluasi pijat bayi yang dilakukan selama 3 minggu pada bayi terjadi peningkatan perkembangan pada motoric kasar, hal ini disebabkan adanya rangsangan melalui sentuhan kulit/pijat ringan pada bayi yang baik akan merangsang saraf otak untuk mengendalikan aktifitas motoric sehingga mampu meningkatkan perkembangan pada motoric kasar. Hasil uji statistic terapi pijat bayi terhadap perkembangan motoric bayi diperoleh $p$ value 0,001 menunjukkan bahwa terapi pijat bayi efektif terhadap perkembangan motorik bayi.

Evaluasi kemajuan perkembangan bayi setelah dilakukan pijat bayi selama 3 minggu memperoleh peningkatan nilai mean, hal ini dapat dilihat pada kemampuan bayi misalnya pada usia 4 bulan bayi sudah bisa tengkurap dan telentang, menumpu badan pada kaki, serta dada terangkat menumpu pada lengan. Hasil ini sama dengan penelitian lain yang membuktikan pijat bayi dapat meningkatkan perkembangan motoric bayi yaitu dengan mengangkat dada dan kedua tangan sebagai penyangga (Ramatian, 2017). Sama halnya penelitian yang dilakukan Puspita, dkk (2014) menyatakan pijat bayi dapat meningkatkan kemampuan dada, mengangkat leher. Demikian juga penelitian yang dilakukan Kusumastuti, et al (2016) melaporkan bayi pada kelompok pijat memiliki perkembangan motorik kasar yang lebih baik daripada kelompok kontrol dengan nilai $p=0,043$.

Setelah dilakukan skrining, peneliti melakukan therapi pijat bayi dalam memberi contoh dan memberikan video pijat bayi kepada responden. Pemberian video pijat bayi dapat meningkatkan 
pengetahuan dan keterampilan responden. Hasil penelitian ini sama penelitian dengan penelitian Astrid Midtsund (2019) dengan tujuan mengeksplorasi pengalaman belajar pijat bayi dan untuk memberikan kesempatan ibu untuk membangun hubungan emosional dan fisik dengan bayi, hasil yang didapatkan yaitu para ibu dalam penelitian di Norwegia ini menikmati pengalaman belajar pijat bayi dan merasa lebih dekat dengan bayi mereka sebagai hasilnya.

Mendidik ibu tentang pijat bayi tentunya memiliki efek yang menguntungkan bagi bayinya, waktu terbaik bagi ibu untuk mendapatkan edukasi pijat bayi. Ibu dapat segera mengenali proses tumbuh kembang anaknya, sehingga memberikan stimulasi dini pada aspek tumbuh kembang anak baik fisik, mental, maupun sosial. Oleh karena itu, keterampilan ibu bermanfaat dalam perkembangan dan proses pertumbuhan anak secara keseluruhan. Pijat bayi dapat diartikan sebagai sentuhan komunikasi yang tepat waktu antara ibu dan bayi (Dewi, 2017). Pijat bayi adalah terapi sentuh tertua dan terpopuler yang dikenal manusia. Pijat bayi sudah dilakukan hampir di seluruh dunia termasuk di Indonesia dan diwariskan. Menyatakan bahwa pijat bayi adalah seni perawatan dan pengobatan kesehatan yang dikenal sejak awal diciptakan manusia di dunia dan telah dipraktikkan berabad-abad lalu secara turun-temurun (Santi, 2012). Stimulasi kemandirian ibu terhadap pertumbuhan dan perkembangan bayi. Pijat bisa menjadi salah satu kegiatan untuk menyalurkan kasih sayang kepada bayinya, efek psikologis yang ditimbulkan oleh kontak kulit-ke-kulit antara ibu dan bayinya (Linda, et al. 2020). 


\section{KESIMPULAN}

DAFTAR PUSTAKA

\section{Pijat bayi merupakan teknik yang sederhana dan efektif} mendukung perkembangan bayi secara keseluruhan. Peran ibu sangat penting dalam proses tumbuh kembang bayi sehingga perlu mengeksplorasi pengalaman belajar ibu melakukan pijat bayi serta membangun hubungan emosional dan fisik dengan bayi. Studi ini menemukan bahwa ibu yang memijat bayinya ternyata menjalin hubungan yang positif dengan bayinya. Hubungan positif ini menjaga kestabilan emosi ibu yang pada gilirannya merangsang ibu untuk meningkatkan produksi ASI

Rezaeian A, Niknejad Jalali A, Mazlom S. An investigation of the effect of implementation of evidence-based care package on the gross motor development of the foster care infants. Evidence Based Care 2013

Anderson LM, Shinn C, Fullilove MT, Scrimshaw SC, Fielding JE, Normand J, et al. The Effectiveness Of Early Childhood Development Programs: A Systematic Review. American Journal Of Preventive Medicine. 2003

Kementrian Kesehatan RI. Pedoman pelaksanaan stimulasi, deteksi dan intervensi dini tumbuh kembang anak di tingkat pelayanan kesehatan dasar. Jakarta. 2009.

Watson J. Child neglect. New South Wales. 2005.

Hurlock. Perkembangan Anak. Edisi keenam. Jilid 2. Jakarta: Erlangga. 2002

Suryawan A, Irwanto. 2012. UK Tumbuh Kembang Anak dan Remaja IDAl Jawa Timur. In: Deteksi Dini Tanda dan Gejala Penyimpangan Pertumbuhan dan Perkembangan Anak. Surabaya)

Holly Tiret, Michigan State University Extension, and Rebecca Hodges, Western Michigan University development intern. 2017 
Jan; 8(1-2): 10

Ays, e Gürol, PhD, Sevinç Polat, PhD. The Effects of Baby Massage on Attachment between Mother and their Infants. Asian Nursing Research 6. 2012

Inal, Sevil \& Yıldız, Suzan. (2012). The Effect Of Baby Massage On Mental-Motor Development Of Healthy Full Term Baby. HealthMED. 6. 578-584

Wei-Peng Lu, Wen-Hui Tsai, Ling-Yi Lin, Rong-Bin Hong \& Yea-Shwu Hwang. The Beneficial Effects of Massage on Motor Development and Sensory Processing in Young Children with Developmental Delay: A Randomized Control Trial Study. Published online: 30 Oct 2018

Fitriani, S., Promosi Kesehatan, Edisi pertama cetakan pertama, Penerbit Graha IImu, Yogyakarta. Hal. 1-2, 87, 176-180, 2011.

Arum Dwi Anjani, Devy Lestari Nurul Aulia, Chablullah Wibisono. Review Article Information Giving Effect To Knowledge Mothers With Babies Of Infant Massage. International Journal of Information Research and Review. 2018. Vol. 05, Issue 07.

Puspita Eka Kurnia Sari. Efektifitas Pijat Bayi Terhadap Pertumbuhan dan Perkembangan Bayi Usia 6 Bulan di Kelurahan Bintaro Jakarta. PSIK Fakultas Kedokteran Universitas Islam Syarif Hidayatulah Jakarta. 2014

Ramatian Simanihuruk. Efektifitas Pijat Bayi Terhadap Pertumbuhan Dan Perkembangan Bayi Usia 6-12 Bulan Di Desa Nifuboke Kecamatan Noemuti Tahun 2017

Kusumastuti Nurry Ayuningtyas, Didik Tamtomo, Harsono Salimo, Effect of Massage on Sleep Quality and Motor Development in Infant Aged 3-6 Months. Journal of Maternal and Child Health. 2016 


\section{Astrid Midtsund, Astrid Litland, Esther Hjälmhult. Mothers'} Experiences Learning and Performing Infant Massage-A Qualitative Study. Journal of Clinical Nursing. 2019. Volume 28, Issue3-4

Dewi, Siska, 2013. Massage and Intake of Proper Nutrition to jumpstart Growth. Yogyakarta: New Library Press Health Agency of Batam, 2017. Health Profile 2016 Batam Batam: Batam City Health Office

Santi, Enidya. 2012. Book Smart Baby Massage for Optimal Growth Shat and Intelligent. Yogyakarta: Red Pinang Publisher.

Linda Meliati, Ni Putu Karunia Ekayani, Siti Khadijah. Effects of the Mother's Individual Stimulation on the Growth and Development of Infants with Low Birth Weight History. Journal of Holistic Nursing and Midwifery. Volume 30, Issue 4 (7-2020) 